\title{
MEDIA SELECTION FOR MYCELIA GROWTH, ANTIFUNGAL ACTIVITY AGAINST WOOD-DEGRADING FUNGI, AND GC-MS STUDY BY PYCNOPORUS SANGUINEUS
}

\author{
Yi P. Teoh, ${ }^{a}$ Mashitah M. Don, ${ }^{\mathrm{a}, *}$ and Salmiah Ujang ${ }^{\mathrm{b}}$ \\ Wood-decaying fungi present a serious threat to items made from \\ rubberwood (Hevea brasiliensis). Though conventional chemical control \\ has been a successful method for preserving wood against stain and \\ decay fungi growth, the effects of these chemicals are of concern \\ because they create problems for the environment and public health. \\ Pycnoporus sanguineus ( $P$. sanguineus), is a white-rot fungus that \\ invades wood during its growth, storage, or use, causing decay or other \\ property changes. It was considered in this work as a potential source of \\ bioactive compounds and investigated for its natural antifungal activity \\ using a minimum inhibitory concentration assay against wood-degrading \\ fungi. It was found that media consisting of $10.0 \mathrm{~g} / \mathrm{L}$ malt extract, yeast \\ extract, dextrose, and maltose, respectively at $\mathrm{pH} 4.7 \pm 0.2$ provided the \\ highest biomass production by $P$. sanguineus. Results showed that the \\ antifungal properties of methanol and water extract of $P$. sanguineus \\ mycelia and supernatant ranged from MIC values of 0.1 to $5.0 \mu \mathrm{g} / \mu \mathrm{L}$. $4 \mathrm{H}-$ \\ Pyran-4-one,2,3-dihydro-3,5-dihydroxy-6-methyl- (DDMP) was found to \\ be the major component in the extract of this fungus, based on analysis \\ using gas chromatography - mass spectrometry.
}

Keywords: Wood-degrading fungi; Pycnoporus sanguineus; Antifungal activity; 4H-Pyran-4-one,2,3dihydro-3,5-dihydroxy-6-methyl- (DDMP)

Contact information: a: School of Chemical Engineering, Universiti Sains Malaysia, 14300 Nibong Tebal, Seberang Perai South, Penang, Malaysia; b: Chemistry and Wood Protection Programme, Forest Product Division, Forest Research Institute of Malaysia (FRIM), 52109 Kepong, Selangor Darul Ehsan, Malaysia;

*Corresponding author: chmashitah@eng.usm.my/ita56@hotmail.com

\section{INTRODUCTION}

Rubberwood is the wood from a para-wood species (Hevea brasiliensis). Its structural elements consist of $61.5 \%$ fiber, $9.5 \%$ vessels, and $29.0 \%$ parenchyma cells. The biodegradation problem is one of the main reasons why rubberwood has been less attractive for wood processing industries and has been almost neglected in the past, although it has been abundant in supply and readily available (Hong 1995; Killmann 2001). Most of the basidiomycetes, such as Schizophyllum commune, Lentinus sajor-caju, Trametes versicolor, Microporus xanthopus, Gloeophyllum trabeum, etc., are normally associated with the white-rot of living trees and on logs, dead twigs, and stumps; such fungi degrade wood, leading to economic losses in forestry (Quiroga et al. 2001; Zjawiony 2004). The high carbohydrate (sugar and starch) reserves deposited in the parenchyma and the lack of phenolic compounds in the wood are the major factors governing the high decay susceptibility of rubberwood (Salmiah 1997). Wood-decaying 
fungi that cause severe breakdown of wood are classified either as brown-rot and whiterot (generally caused by basidiomycetes) fungi or as soft-rot (caused by ascomycetes and dueteromycetes as imperfect fungi) fungi (Hong et al. 1999). Although chemical agents are commonly employed to control wood degradation caused by stain and decay fungi, the application of chemical fungicides has become limited due to the requirement for low pesticide residues in products and to the increasing problems associated with resistance to the active principles (Mommaerts et al. 2008). According to Kinay et al. (2007), several synthetic fungicides have been removed from the market due to possible toxicological risks. Therefore, there is a significant requirement for the development of new and more environment-friendly formulations that reduce synthetic fungicide applications and minimize the pressure for resistance development.

Antifungal secondary metabolites isolated from the heartwood of plants have been considered to contribute to trees' resistance against wood-degrading fungi (Quiroga et al. 2001). There is a paucity of information on the use of the extracts of herbs for the control of wood degradation by wood-rot fungi. As reported by Ejechi (2001), the leaf extract from Acalypha hispida (Euphorbiceae), a herbaceous ornamental plant, contains phenolic compounds that are capable of antagonizing wood-rot fungi. On the other hand, Verma et al. (2007) claim that Trichoderma spp. is currently the most extensively investigated biocontrol fungi for forest product preservation, particularly in protecting wood against basidiomycetes. As an example, Ejechi (1997) investigated the ability of Trichoderma viride to retard the decay of obeche (Triplochiton scleroxylon) wood in the field for 11 months covering dry and wet seasons in a tropical environment. The result obtained showed that the $T$. viride exhibited total inhibition of the decay by Gloeophyllum sepiarium and Pleurotus ostreatus through the means of mycoparasitism and competition for nutrients.

Filamentous fungi are a major source of bioactive secondary metabolites. Through the study of ecological chemical interactions, researchers have established the existence of biochemical pathways with the sole purpose of producing mycotoxins and other natural products in fungi (Frisvad et al. 2008). In this approach, fungi have been widely applied in agriculture as biocontrol for pest management. According to Reddy and Mathew (2001), there has been much interest in the possible use of wood-rotting fungi as a biodegradation agent, particularly in the case of white-rot fungi. White-rot fungi are a physiological rather than a taxonomic grouping, belonging to the basidiomycetes group, and they exhibit the most efficient and extensive lignin degradation (Pointing 2001). These can be used as the active ingredients of bioherbicide, bioinsecticide, and biofungicide products (Bennett et al. 2001). Exploration, conservation, and utilization of the fungi belonging to the basidiomycetes group can be expected to prove beneficial for humankind, as well as the environment.

Pycnoporus sanguineus is a white-rot fungus, also of a slow-growing saprophytic nature, belonging to the basidiomycetes of the family of Polyporaceae (Smania et al. 1995; Siqueira et al. 1997). It is unique in its ability to completely degrade all components of lignocellulosic materials. The ability of this fungus to degrade lignin, as well as polysaccharides found in the cellulose and hemicelluloses, indicates that it has the potential not only to act as a biological pretreatment, but also to degrade all major components of lignocelluloses and yield valuable products (Park et al. 2006; Teoh and 
Mat Don 2011). Recently, production of enzymatic activity has been shown (e.g., CMCase, FPase, and $\beta$-glucosidase) when $P$. sanguineus was grown in a suitable culture medium (Teoh and Mashitah 2010). In fact, it was reported that $P$. sanguineus had produced laccase as the sole lignolytic enzyme to degrade selected agro-residue in solidstate fermentation (Teoh and Mat Don 2011). On the other hand, this fungus is very common on dead trees and plays an important ecological role in degrading woody forest litter (Djarwanto and Tachibana 2009). Meanwhile, the antimicrobial activity of $P$. sanguineus had been known since 1946, when poliporin was isolated against grampositive and gram-negative bacteria and shown to be non-toxic to experimental animals (Rosa et al. 2003). The basidiomes of $P$. sanguineus had already been in use for a long time by Brazilian indigenous people to prevent haemorrhages and by American and African indigenous tribes for treatment of several ailments (Smania et al. 1995; Rosa et al. 2003).

Thus, the present study is aimed to determine the nutritional requirement of $P$. sanguineus strains for mycelia growth and to provide information regarding its growth profile. The ability of a compound extracted from $P$. sanguineus culture to inhibit the growth of various wood-degrading fungi species will also be identified.

\section{MATERIALS AND METHODS}

\section{Fungal Strain}

The fungal strain, $P$. sanguineus was obtained from the Biocomposite and Protection of Timber Forest Products Laboratory, Forest Research Institute Malaysia (FRIM), Kepong, Malaysia. This stock culture was grown on agar slants comprised of 20 $\mathrm{g} / \mathrm{L}$ glucose, $10 \mathrm{~g} / \mathrm{L}$ yeast extract, and $10 \mathrm{~g} / \mathrm{L}$ malt extract agar. The $\mathrm{pH}$ of the media was adjusted to $7.0 \pm 0.2$ prior to autoclaving at $121^{\circ} \mathrm{C}$ for 15 minutes. The culture was grown at $30^{\circ} \mathrm{C}$ and maintained on agar slants prior for subsequent studies.

\section{Wood-degrading Fungi Used}

Selected wood-degrading fungal strains of Trametes versicolor, Trametes feei, Trametes menziezi, Lentinus sp., Lentinus sajor-caju, Lentinus strigosus, Microporus affinis, Microporus xanthopus, and Gloeophyllum trabeum were obtained from the Biocomposite and Protection of Timber Forest Products Laboratory, Forest Research Institute Malaysia (FRIM), Kepong, Malaysia. The stock cultures were grown at $30^{\circ} \mathrm{C}$ and maintained on malt extract agar slants for subsequent studies.

\section{Mycelial Suspension Preparation}

A mycelia suspension was prepared by suspending mycelia discs from 7-days-old culture plates in sampling bottles containing sterilized distilled water and $0.1 \%(\mathrm{v} / \mathrm{v})$ Tween 80 . The disc of $5 \mathrm{~mm}$ diameter was cut on the mycelia mats of the agar plate using a sterilized cork borer. A total of 10 discs for every $100 \mathrm{~mL}$ of sterilized water were vortexed for 5 minutes in order to make the mycelial suspensions homogenous. 


\section{Mycelial Extract Preparation}

Ten milliliters $(10 \% \mathrm{v} / \mathrm{v})$ of the mycelia suspension was added to $90 \mathrm{~mL}$ of medium containing different typical compositions in $250 \mathrm{~mL}$ Erlenmeyer flasks. The medium was autoclaved at $121^{\circ} \mathrm{C}$ for 15 minutes before transferring the mycelia suspension into the culture media. The culture was shaken at $200 \mathrm{rpm}$ in an incubator shaker at $30 \pm 2^{\circ} \mathrm{C}$ for 5 days. The culture broth was then harvested and centrifuged at $4000 \mathrm{x}$ g for 15 minutes. The residue (also known as mycelia biomass) was then dried and homogenized prior to the extraction process. Meanwhile, the supernatant was evaporated using a rotary evaporator and the residues were maintained in vacuum until the extraction process was carried out.

\section{Effect of Different Media on P. sanguineus Growth in Shake Flask Culture}

The effect of different growth media on growth of $P$. sanguineus was studied under shake flask culture conditions. The medium compositions are listed in Table 1 . The medium $(90 \mathrm{~mL})$ was adjusted to $\mathrm{pH} 4.7 \pm 0.2$ using $1 \mathrm{M} \mathrm{NaOH}$ and $1 \mathrm{M} \mathrm{HCl}$ and incubated with $10 \mathrm{~mL}$ fungal mycelia suspension for 5 days at $30 \pm 2^{\circ} \mathrm{C}$ and $200 \mathrm{rpm}$. The fungal biomass was vacuum-filtered and dried at $60^{\circ} \mathrm{C}$ in an oven for 24 hours until constant weight was achieved. The biomass concentration was determined as shown in Eqn. (1).

$$
\text { Myceliadry weight }(\mathrm{g} / \mathrm{L})=\frac{\mathrm{g}(\text { dried mycelia filter paper })-\mathrm{g}(\text { filter paper })}{\text { Volumemeasure }(\mathrm{L})}
$$

A control experiment was also carried out using only distilled water as the medium.

Table 1. Composition of Different Media for Growth of $P$. sanguineus in Shake Flask Culture

\begin{tabular}{|c|c|c|c|c|c|}
\hline Composition & $\begin{array}{c}\text { Medium 1 } \\
(\mathrm{g} / \mathrm{L})\end{array}$ & $\begin{array}{c}\text { Medium 2 } \\
(\mathrm{g} / \mathrm{L})\end{array}$ & $\begin{array}{c}\text { Medium 3 } \\
(\mathrm{g} / \mathrm{L})\end{array}$ & $\begin{array}{c}\text { Medium 4 } \\
(\mathrm{g} / \mathrm{L})\end{array}$ & $\begin{array}{c}\text { Medium 5 } \\
(\mathrm{g} / \mathrm{L})\end{array}$ \\
\hline Malt extract & - & - & 10.0 & 10.0 & 10.0 \\
\hline Yeast extract & 10.0 & 10.0 & & 10.0 & 10.0 \\
\hline Peptone & 3.0 & 3.0 & 3.0 & - & - \\
\hline Dextrose & - & - & 10.0 & - & 10.0 \\
\hline Glucose & 20.0 & 20.0 & - & 20.0 & - \\
\hline $\mathrm{Maltose}_{\mathrm{KH}_{2} . \mathrm{PO}_{4}}$ & - & - & 10.0 & - & 10.0 \\
\hline $\mathrm{MgSO}_{4} .7 \mathrm{H}_{2} \mathrm{O}$ & - & 0.5 & 0.5 & - & - \\
\hline
\end{tabular}

\section{Batch Solvent Extraction Process}

A hydrodistillation process was carried out. Dry residues (100 g) either obtained from the mycelia or supernatant were boiled in water and methanol (ratio $1 \mathrm{~g}: 20 \mathrm{~mL}$ ) for 48 hours. The percentage yield for water and methanol was about $1.21 \%$ and $2.95 \%$, respectively. Then, the crude extract obtained was dried and kept at $4^{\circ} \mathrm{C}$ for further analysis. 


\section{Minimum Inhibitory Concentration (MIC) Assay}

A broth dilution method using a 96-well microtitre plate was employed for minimum inhibitory concentration (MIC) determination. Six different concentrations of each of the extracts were prepared ranging from 0.1 to $5 \mu \mathrm{g} / \mu \mathrm{L}$. Briefly, the wooddegrading fungi mycelia suspension of each strain was prepared and standardized according to $0.5 \mathrm{McFarland}$ standard turbidity. Then, the crude extract obtained was dissolved into 5\% dimethyl sulfoxide (DMSO). Each well contained malt extract broth (Media 5, Table 1) with $0.09 \mathrm{~mL}$ volume of serially diluted crude extracts. Each well was inoculated with the mycelial suspension of wood-degrading fungi in a final volume of 0.1 $\mathrm{mL}$. The control contained only malt extract in the medium. Incubations were performed at $30^{\circ} \mathrm{C}$ for 48 hours. The effectiveness of inhibition was quantified by adding $0.02 \mathrm{~mL}$ of the yellow tetrazolium MTT (3-(4,5-dimetylthylthiazolyl-2)-2,5-diphenyltetrazolium bromide) reagent into each well. The results were obtained after an incubation period of 2 hours. Formation of a blue colour indicated fungal growth, while clear colour of the well indicated growth inhibition.

MIC was defined as the lowest concentration of fungal mycelia extract to which no growth of wood-degrading fungi was observed after the incubation period. DMSO at the concentrations used did not interfere with the reaction conditions (Slanc et al. 2004).

\section{Analytical method}

The crude extract was dissolved with $70 \%(\mathrm{v} / \mathrm{v})$ ethanol prior to the gas chromatography mass spectrometry (GC-MS) analysis. In this study, a GC-MS was used to analyze the sample qualitatively by referring to the molecular weight of the compounds in a library (Model: NIST), which was incorporated into it. The gas chromatography analyses were performed using a Perkin Elmer Clarus 600 gas chromatograph equipped with an ELITE-5 column. The gas chromatograph was coupled to the Perkin Elmer 600T mass spectrometer. The oven temperature was programmed at $65^{\circ} \mathrm{C}$ for 4 minutes and then increased to $280^{\circ} \mathrm{C}$ at a rate of $8^{\circ} \mathrm{C} / \mathrm{min}$.

\section{RESULTS AND DISCUSSION}

\section{Effect of Different Growth Media on P. sanguineus Growth in Shake Flask Culture}

Figure 1 shows the effect of different media on the growth of $P$. sanguineus in shake flask culture. The highest biomass was recorded in Medium 5 and therefore used throughout the study.

Of all the mineral nutrients in the culture media, nitrogen is usually required in the largest amounts and can be the limiting factor for fungal growth (Deacon 2006). In addition, it serves as a mean of physiological control and regulation of microorganism metabolites (Thomas et al. 1996). In this study, malt and yeast extract served as the key component in the media for $P$. sanguineus growth, which is similar to results reported by Yahaya (2008). According to Cheng et al. (1991), yeast extract was the best supplement for a nitrogen source and provided convenient growth factors for most microorganisms. The results are inconsistent with those of Fasidi and Olorunmaiye (1994), who found that 
yeast extract, a complex nitrogen source, sustained the highest growth of Pleurotus tuberregium. On the other hand, the simulating effect of malt extract may be attributed to its carbon and protein components in the media (Yahaya 2008) that could have improved the mycelia growth of fungi, particularly of Agaricus bisporus (Friel and McLoughlin 2000) and Antrodia cinnamomea (Lin and Chen 2007).

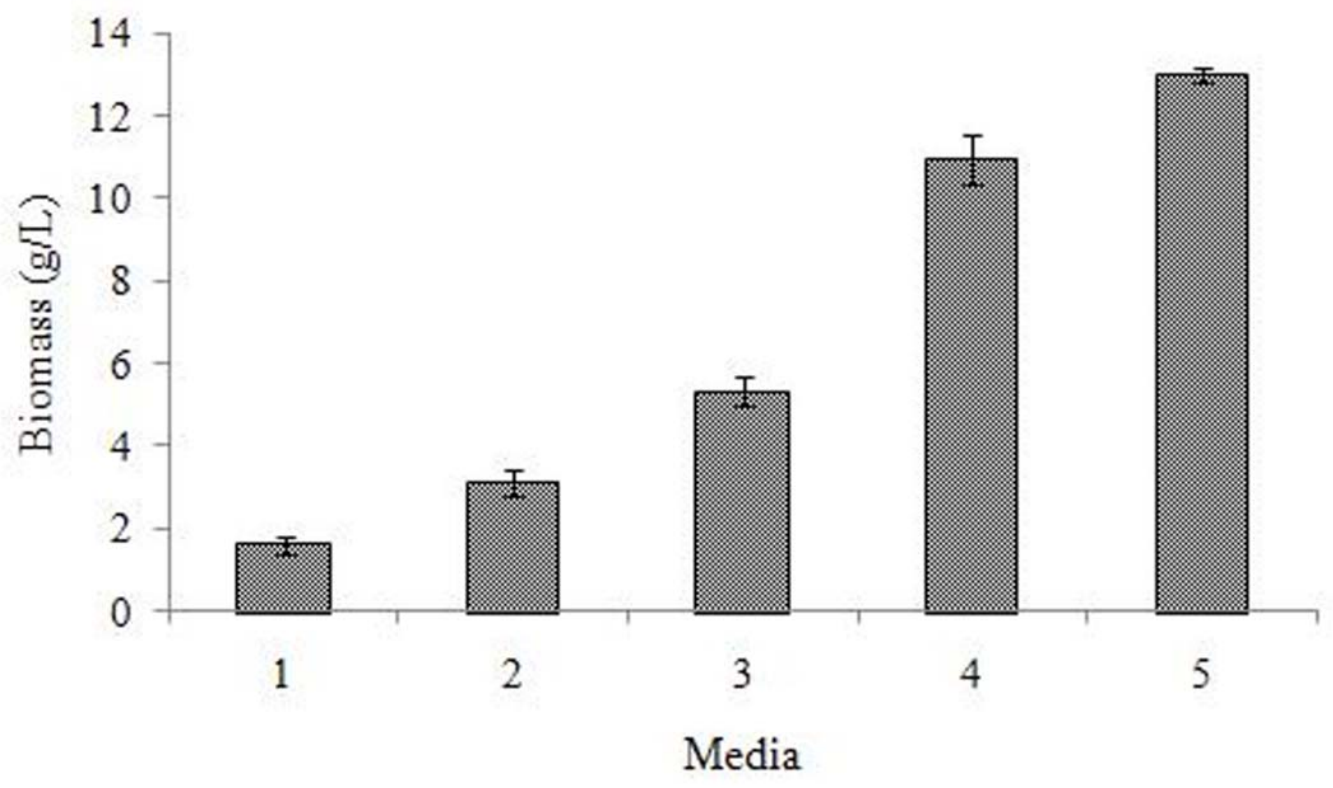

Fig. 1. Biomass of $P$. sanguineus in different production media

Glucose is another nutrient that has been used as an excellent carbon source for growth, and it interferes with the biosynthesis of many secondary metabolites (Demain 1986). Medium 5 yielded the higher biomass as compared to Medium 4 (Fig. 1). Herewith, the result contrasted with the studies undertaken by Martin et al. (1999), Jonathan and Fasidi (2001), and Lin and Chen (2007). Martin et al. (1999) reported that carbon catabolite regulation of penicillin biosynthesis and cephalosporin production is exerted by glucose. Jonathan and Fasidi (2001) indicated that the preference of glucose over other carbon compounds on the growth of Psathyerella atroumbonata may be due to the ease with which this sugar was metabolized to produce cellular energy. Besides, Lin and Chen (2007) concluded that glucose was utilized preferentially for mycelial growth in submerged cultivation of $A$. cinnamomea. However, several researchers had found that dextrose and maltose can serve as a better carbon source during the mycelial incubation process. Pandey et al. (2005) observed that dextrose was an excellent carbon source for antibiotic production by Streptomyces kanamyceticus. In addition, Manjunathan and Kaviyarasan (2010) reported that dextrose proved to be the best source of carbon for the growth of Lentinus tuberregium, and this was followed by maltose.

\section{Antifungal Activity from $P$. sanguineus}

The results obtained from this study concerning the biological activity of the antifungal agents produced by $P$. sanguineus against different species of wood-degrading 
fungi are recorded in Table 2. It is clear that the minimum inhibitory concentration (MIC) depended mainly on the types of solvent used and the tested fungal strains. Results showed MIC values ranging from 0.1 to more than $5.0 \mu \mathrm{g} / \mu \mathrm{L}$. The methanolic extract of $P$. sanguineus showed better inhibition on the tested wood-degrading fungi, particularly against Lentinus sp. with MIC $0.1 \mu \mathrm{g} / \mu \mathrm{L}$.

As reported by Anke (1989), most basidiomycetes produce a great variety of antimicrobial activities. As shown in Table 2, the extract of $P$. sanguineus exhibited considerable in-vitro activity against all filamentous fungi tested. This observation was in agreement with that reported by Smania et al. (1995), who found that the fraction obtained from the culture fluid of $P$. sanguineus fungus contained a compound with biological activity against strains of Escherichia coli, Klebsiella pneumonia, Pseudomonas aeruginosa, Salmonella typhi, Staphylococcus aureus, and members of the genus Streptococcus. These results show that $P$. sanguineus can be used as an alternative to treat various types of wood-degrading fungi.

Concerning the anti-fungal effect, the result showed that the effectiveness of antifungal activity using mycelia extract was higher in comparison to that from the supernatant. In the light of the experimental results concerning the anti-fungal activity against the tested fungal organisms, the results recorded in Table 2 clearly showed that the methanol extracts of $P$. sanguineus gave better biological activity as compared to the water extract. This observation is in slight agreement with the study carried out by Parthasarathy et al. (2009), who indicated that the relatively wider spectrum of activity of the methanol extracts over the positive control was significant from the disc diffusion assay, while the water extract was devoid of any antimicrobial activity. Oppositely, AliShtayeh and Abu Ghdeib (1999) observed success with water extracts against dermatophytes. According to Webster et al. (2008), alcohol extracts provide a more complete extraction, including less polar compounds, and many of these extracts have been found to possess anti-fungal properties.

Table 2. Composition of the Extract from $P$. sanguineus Mycelia

\begin{tabular}{|c|c|c|c|c|}
\hline & \multicolumn{4}{|c|}{$\begin{array}{c}\text { Minimum inhibitory concentration (MIC) obtained by extract } \\
\text { of } P \text {. sanguineus }(\mu \mathrm{g} / \mu \mathrm{L})\end{array}$} \\
\hline Wood-degrading fungi species & $\mathrm{My}^{\mathrm{m}}$ & $\mathrm{My}^{\mathrm{w}}$ & Sus $^{m}$ & Sus $^{\mathrm{w}}$ \\
\hline Schizophyllum commune & 5.0 & $>5$ & $>5$ & $>5$ \\
\hline Trametes versicolor & 1.3 & $>5$ & $>5$ & $>5$ \\
\hline Trametes elegans & 2.5 & 5 & 5 & 5 \\
\hline Trametes feei & 1.3 & 5 & $>5$ & $>5$ \\
\hline Trametes menziezi & 0.3 & 5 & 5 & 5 \\
\hline Lentinus sp. & 0.1 & 2.5 & 5 & 5 \\
\hline Lentinus sajor-caju & 1.3 & 5 & $>5$ & $>5$ \\
\hline Lentinus strigosus & 2.5 & $>5$ & $>5$ & $>5$ \\
\hline Microporus affinis & 0.3 & 2,5 & 2.5 & 5 \\
\hline Microporus xanthopus & 0.3 & 2.5 & 2.5 & 5 \\
\hline Gloeophyllum trabeum & 2.5 & 5 & $>5$ & $>5$ \\
\hline Eariella scabrous & 2.5 & 5 & $>5$ & $>5$ \\
\hline
\end{tabular}

${ }^{*}$ The symbols My and Sus denote the type of residues used by mycelia and supernatant, respectively after incubation process. The superscripts $m$ and $w$ denote the extraction carried out by methanol and water, respectively. In this study, the tested concentration was $5 \mu \mathrm{g} / \mu \mathrm{L}$. Activity 
concentration: weak activity: MIC $>5 \mu \mathrm{g} / \mu \mathrm{L}$; moderate activity: $1 \mu \mathrm{g} / \mu \mathrm{L}<\mathrm{MIC} \leq 5 \mu \mathrm{g} / \mu \mathrm{L}$; strong activity: MIC $\leq 1 \mu \mathrm{g} / \mu \mathrm{L}$.

\section{GC-MS Analysis}

The interpretation of the mass spectra obtained by the GCMS method was conducted using the database of the National Institute of Standards and Technology (NIST). The spectrum of unknown components from the sample was compared with the spectrum of the known components stored in the NIST library version 2.0. On this basis the name, molecular weight, and structure of the components of the tested materials were ascertained. Concerning the effect of anti-fungal activity towards fungi tested, this study involved only the extract from mycelia of $P$. sanguineus, which performed much better compared to those from culture suspension. Figures 2 and 3 show the GCMS chromatogram of the extracts from $P$. sanguineus mycelia. The corresponding major components present in the extract of this fungus based on the GCMS spectrum are recorded in Table 3.

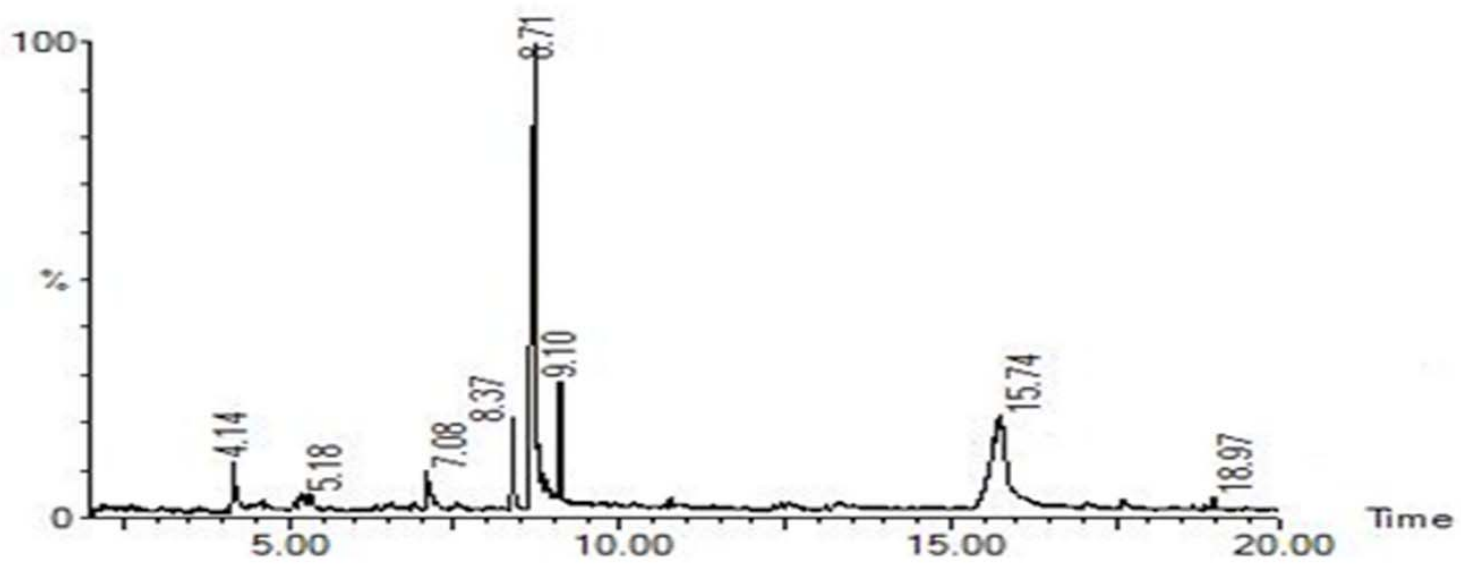

Fig. 2. Chromatogram for the methanol extract from $P$. sanguineus

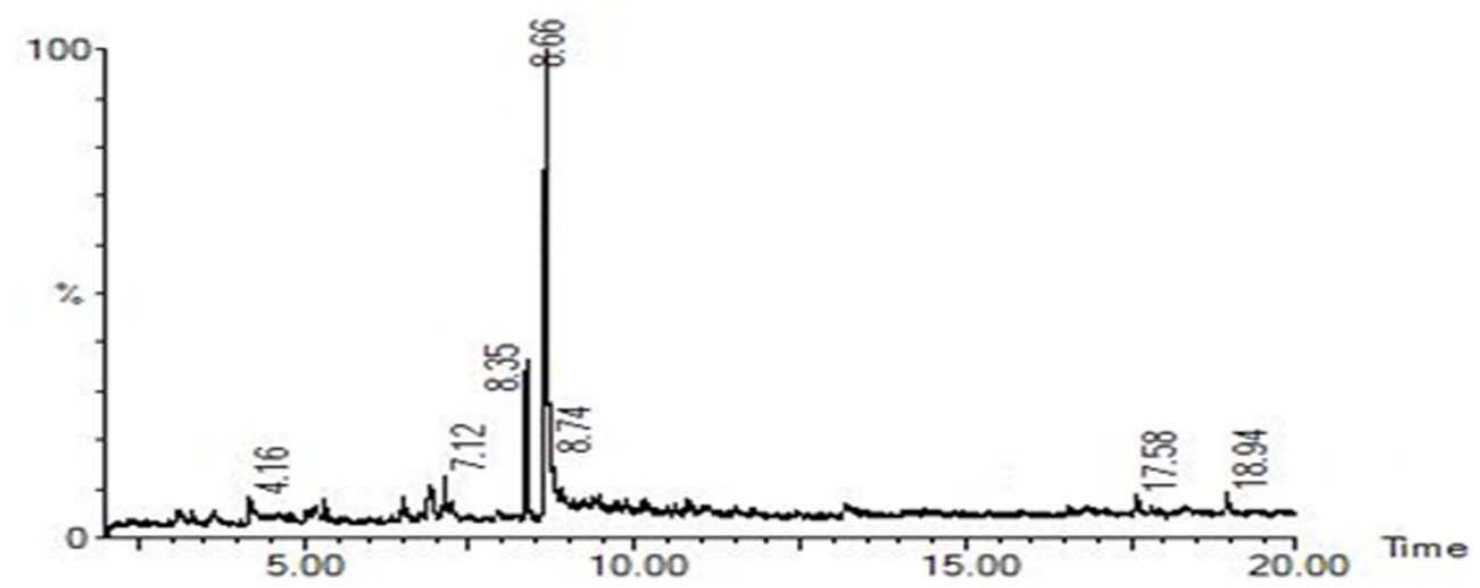

Fig. 3. Chromatogram for the water extract from $P$. sanguineus 
As shown in Table 3, the major component that was present in the methanol and water extracts of $P$. sanguineus was 4H-pyran-4-one,2,3-dihydro-3,5-dihydroxy-6methyl- (DDMP). It was suggested that the formation of DDMP might be the intermediate product during the aqueous Maillard reaction of D-glucose, hexoses, dextrose, and maltose (Preininger et al. 2009). For the effect of anti-fungal activities of these extracts, the results showed that the methanol extract had a higher percentage of DDMP as compared to that in water extract. Thus, the methanol extract provided a better result with lower MIC value to inhibit the growth of fungi tested. Based on previous studies, DDMP was first identified from Phaseolus coccineus by Yoshiki et al. (1994). In addition, several researchers had investigated several important biological activities of DDMP, such as anti-alpha-glucosidase activity in patients with diabetes mellitus (Quan et al. 2003), reactive oxygen-scavenging activity (Takara et al. 2007), anti-mutagenic activity against arylamine and 2-acetoxyacetylaminofluorene (2AAAF)-induced DNA damage in Chinese hamster ovary cells (Berhow et al. 2000), and also anti-tumour activity (Ban et al. 2007). Meanwhile, it was reported that the flavones, flavonoids, and flavonols had a phenolic structure with one carbonyl group, which was often found to be effective in-vitro as an antimicrobial substance against the wild array of microorganisms (Das et al. 2010). In fact, DDMP belongs to the flavanoid fraction, a group of complex natural products of current medicinal interest, in which its anti-microbial, anti-oxidant, and anti-inflammatory properties have been recognized (Kumar and Maneemegalai 2008; Taylor et al. 2009; Chaturvedi et al. 2010; Kumar et al. 2010).

Table 3. Composition of the Extract from P. sanguineus Mycelia

\begin{tabular}{|c|c|c|c|c|c|}
\hline & & $\mathrm{My}^{\mathrm{m}}$ & & & $\mathrm{My}^{\mathrm{w}}$ \\
\hline $\begin{array}{l}\text { Retention } \\
\text { time } \\
\text { (minutes) }\end{array}$ & $\begin{array}{l}\text { Area } \\
(\%)\end{array}$ & Chemical composition & $\begin{array}{l}\text { Retention } \\
\text { time } \\
\text { (minutes) }\end{array}$ & $\begin{array}{l}\text { Area } \\
(\%)\end{array}$ & Chemical composition \\
\hline 4.14 & 2.33 & $\begin{array}{l}\text { 2-Propanone,1,3- } \\
\text { dihydroxy- }\end{array}$ & 4.16 & 1.48 & $\begin{array}{l}\text { 2-Propanone,1,3- } \\
\text { dihydroxy- }\end{array}$ \\
\hline 7.08 & 0.74 & $\begin{array}{l}\text { 4,5-Diamino-6-hydroxy } \\
\text { pyrimidine }\end{array}$ & 7.12 & 0.56 & $\begin{array}{l}\text { 4,5-Diamino-6-hydroxy } \\
\text { pyrimidine }\end{array}$ \\
\hline 8.38 & 2.04 & N-Aminomorpholine & 8.35 & 1.64 & N-Aminomorpholine \\
\hline 8.71 & 20.58 & $\begin{array}{l}\text { 4H-Pyran-4-one,2,3- } \\
\text { drhydro-3,5-dihydroxy-6- } \\
\text { methyl- }\end{array}$ & 8.66 & 5.43 & $\begin{array}{l}\text { 4H-Pyran-4-one,2,3- } \\
\text { drhydro-3,5-dihydroxy- } \\
\text { 6-methyl- }\end{array}$ \\
\hline 9.10 & 1.92 & $\begin{array}{l}\text { 2(3H)-Furanone, } \\
\text { dihydro-4-hydroxy }\end{array}$ & 8.74 & 0.39 & $\begin{array}{l}\text { 2(3H)-Furanone, } \\
\text { dihydro-4-hydroxy }\end{array}$ \\
\hline 15.75 & 16.01 & Sucrose & 17.58 & 0.42 & $\begin{array}{l}\text { 3-Deoxy-d-mannoic } \\
\text { lactone }\end{array}$ \\
\hline 18.98 & 0.44 & Xylitol & 18.94 & 0.39 & Xylitol \\
\hline
\end{tabular}

*The symbol My denotes the type of residues used by mycelia after incubation process. The superscripts $m$ and $w$ denote the extraction carried out by methanol and water, respectively.

These results indicate that the presence of chemical compounds in $P$. sanguineus might be the reason for it to have anti-fungal activities against the wood-degrading fungi. 


\section{CONCLUSIONS}

It was found that $P$. sanguineus yielded the highest growth in Medium 5, comprising of $10.0 \mathrm{~g} / \mathrm{L}$ yeast extract, $10.0 \mathrm{~g} / \mathrm{L}$ malt extract, $10.0 \mathrm{~g} / \mathrm{L}$ dextrose, and 10.0 $\mathrm{g} / \mathrm{L}$ maltose at $\mathrm{pH} 4.7 \pm 0.2$. P. sanguineus is a potential source of bioactive compounds, and the results revealed that the methanol extract gave better antifungal activity compared to that of water extract a with lower MIC value. In addition, quantitative analysis using a GC-MS showed the presence of DDMP, a flavanoid compound, which due to the reaction of glucose with complex nitrogen may be formed during the fermentation process. This phenomenon thus could explain the antifungal properties of the $P$. sanguineus. These results can help to justify the use of $P$. sanguineus for the treatment against various species of wood-degrading fungi.

\section{ACKNOWLEDGMENTS}

The authors gratefully acknowledge the National Science Fellowship (NSF) from the Ministry of Science, Technology and Innovation (MOSTI) of Malaysia and the Research University (RU) grant (Grant Account No. 814057) provided by University Sains Malaysia to support this research work. The authors would also like to extend their gratitude to Dr. Salmiah Ujang of the Forest Research Institute of Malaysia (FRIM) for supplying the stock culture of fungus.

\section{REFERENCES CITED}

Ali-Shtayeh, M. S., and Abu Ghdeib, S. I. (1999). "Antifungal activity of plant extracts against dermatophytes,” Mycoses 42, 665-672.

Anke, T. (1989). "Basidiomycetes: A source for new bioactive secondary metabolites," Prog. Ind. M. 27, 51-66.

Ban, J. O., Hwang, I. G., Kim, T. M., Hwang, B. Y., Lee, U. S., Jeong, H. S., Yoon, Y. W., Kim, D. J., and Hong, J. T. (2007). "Anti-proliferate and pro-apoptotic effects of 2,3-dihydro-3,5-dihydroxy-6-methyl-4H-pyranone through inactivation of $\mathrm{NF}_{\mathrm{K}} \mathrm{B}$ in human colon cancer cells," Arch. Pharmacal. Res. 30(11), 1455-1463.

Bennett, J. W., Cornick, W. J., Daigle, D., and Wunch, K. (2001). "Formulation of fungi for in-situ bioremediation," In: Gadd, G.M. (ed.), Fungi in Bioremediation, British Mycologica Society, pp. 97-112.

Berhow, M. A., Wagner, E. D., Vaughn, S. F., and Plewa, M. J. (2000). "Characterization and antimutagenic activity of soybean saponins," Mutat. Res-Fund. Mol. M. 448(1), 11-22.

Chaturvedi, A., Singh, S., and Nag, T. N. (2010). "Antimicrobial activity of flavonoids from in vitro tissue culture and seeds of Gossypium species," Rom. Biotech. Lett. 15(1), 4959-4963. 
Cheng, P., Mueller, R. E., Jaeger, S., Bajpai, R., and Iannotti, E. L. (1991). "Lactic acid production from enzyme-thinned corn starch using Lactobacillus amylovorus," J. Microbiol. 7, 27-34.

Das, K., Tiwari, R. K. S., and Shrivastava, D. K. (2010). "Techniques for evaluation of medicinal plant products as antimicrobial agent: Current methods and future trends." J. Med. Plants Res. 4(2), 104-111.

Deacon, J. W. (2006). "Fungal nutrition," Fungal Biology, $4^{\text {th }}$ Edition, Blackwell Publishing Ltd., British, Ch. 6.

Demain, A. L. (1986). "Regulation of secondary metabolism in fungi," Pure Appl. Chem. 58(2), 219-226.

Djarwanto, and Tachibana, S. (2009). "Screening of fungi capable of degrading lignocelluloses from plantation forests," Pak. J. Biol. Sci. 12(9), 669-675.

Ejechi, B. O. (1997). "Biological control of wood decay in an open tropical environment with Penicillium sp. and Trichoderma viride," Int. Biodeterior. Biodegrad. 39(4), 295299.

Ejechi, B. O. (2001). "Wood biodeterioration control potential of Acalypha hispida leaf phenolic extract in combination with Trichoderma viride culture filtrate," World J. Microbiol. Biotechnol. 17, 561-565.

Fasidi, I. O., and Olorunmaiye, K. S. (1994). "Studies on the requirement for vegetative growth of Pleurotus tuberregium (Fr) Sing., a Nigeria mushroom," Food Chem. 50, 397-401.

Friel, M. T., and McLoughlin, A. J. (2000). "Production of a liquid inoculum/spawn of Agaricus bisporus," Biotechnol. Lett. 22, 351-354.

Frisvad, J. C., Andersen, B., and Thrane, U. (2008). "The use of secondary metabolite profiling in chemotaxonomy of filamentous fungi," Mycol. Res. 112, 231-240.

Hong, L. T. (1995). Rubberwood Utilization: A Success Story. Paper presented at XX International Union of Forestry Research Organizations (IUFRO) World Congress, Tampere, Finland.

Hong, L. T., Wong, A. H. H., and Ho, Y. F. (1999). "Durability of rubberwood,” In: Hong, L. T., and Sim, H. C. (eds.), Rubberwood Processing and Utilization, Forest Research Institute Malaysia (FRIM), Kepong, Malaysia, p. 43-55.

Jonathan, S. G., and Fasidi, I. O. (2001). "Effect of carbon, nitrogen and mineral sources on a growth of Psathyerella atroumbonata (Pegler), a Nigeria edible mushroom," Food Chem. 72, 479-483.

Killmann, W. (2001). Non-Forest Tree Plantations, Forest Plantations Thematic Papers, Forestry Department-Food and Agriculture Organization of the United Nations, 17 pages.

Kinay, P., Mansour, M. F., Gabler, F. M., Margosan, D. A., and Smilanick, J. K. (2007). "Characterization of fungicide-resistant isolates of Penicillium digitatum collected in California," Crop Prot. 26, 647-656.

Kumar, M. S., and Maneemegalai, S. (2008). "Evaluation of larvicidal effect of Lantana camara Linn against mosquito species Aedes aegypti and Culex quinquefasciatus," Adv. Biol. Res. 2(3-4), 39-43. 
Kumar, P. P., Kumaravel, S., and Lalitha, C. (2010). "Screening of antioxidant activity, total phenolics and GC-MS study of Vitex negundo," Afr. J. Biochem. Res. 47(7), 191-195.

Lin, E. S., and Chen, Y. H. (2007). "Factors affecting mycelia biomass and exopolysaccharide production in submerged cultivation of Antrodia cinnamomea using complex media," Bioresource Technol. 98, 2511-2517.

Manjunathan, J. and Kaviyarasan, V. (2010). "Studies on the growth requirements of Lentinus tuberregium (Fr.), an edible mushroom," Middle-East J. Sci. Res. 5(2), 8185 .

Martin, J. F., Casqueiro, J., Kosalkova, K., Marcos, A. T., and Gutierrez, S. (1999). "Penicillin and cephalosporin biosynthesis: Mechanism of carbon catabolite regulation of penicillin production," Antonie Leeuwenhoek. 75, 21-31.

Mommaerts, V., Platteau, G., Boulet, J., Sterk, G., and Smagghe, G. (2008). "Trichoderma-based biological control agents are compatible with the pollinator Bombus terrestris: A laboratory study," Biol. Control. 46, 463-466.

Pandey, A., Shukla, A., and Majumdar, S. K. (2005). "Utilization of carbon and nitrogen sources by Streptomyces kanamyceticus M27 for the production of an anti-bacterial antibiotic," Afr. J. Biotechnol. 4(9), 909-910.

Park, C., Lee, B., Han, E.J., Lee, J., and Kim, S. (2006). "Decolorization of acid black 52 by fungal immobilization," Enzyme Microb. Technol. 39, 371-374.

Parthasarathy, S., Azizi, J. B., Ramanathan, S., Ismail, S., Sasidharan, S., Said, M. I. M., and Mansor, S. M. (2009). "Evaluation of antioxidant and antibacterial activities of aqueous, methanolic and alkaloid extracts from Mitragyna speciosa (Rubuaceae family) leaves," Molecules 14, 3964-3974.

Pointing, S. B. (2001). "Feasibility of bioremediation by white-rot fungi," Appl. Microbiol. Biotechnol. 57, 20-33.

Preininger, M., Gimelfarb, L., Li, H. C., Dias, B. E., Fahmy, F., and White, J. (2009). "Dihydromaltot (2,3-dihydro-5-hydroxy-6-methyl-4H-pyran-4-one): Identification as a potent aroma compound in Ryazhenka kerif and sensory evaluation," Expression Multidisciplinary Flavour Science, London, United Kingdom, 410 pages.

Quan, J., Yin, X., Jin, M., and Shen, M. (2003). "Study on the inhibition of alphaglucosidase by soyasaponins," Zhong Yao Cai 26(9), 654-656.

Quiroga, E. N., Sampietro, A. R., and Vattuone, M. A. (2001). "Screening antifungal activities of selected medicinal plant," J. Ethnopharmacol. 74, 89-96.

Reddy, C. A., and Mathew, Z. (2001). "Bioremediation potential of white rot fungi," In: Gadd, G. M. (ed.), Fungi in Bioremediation, British Mycological Society, pp. 52-79.

Rosa, L. H., Machado, K. M., Jacob, C. C., Capelari, M., Rosa, C. A., and Zani, C. L. (2003). "Screening of Brazilian basidiomycetes for antimicrobial activity," Mem. Inst. Oswaldo Cruz, Rio de Janeiro. 98(7), 967-974.

Salmiah, U. (1997). Basidiomycota in Forest Reserves and Plantation Forest in Peninsular Malaysia. PhD Thesis, University of Portsmouth, United Kingdom, 306 pages.

Siqueira, E. M. D. A., Mizutai, K., and Giglio, J. R. (1997). “Pycnoporus sanguineus: A novel source of $\alpha$-amylase," Mycol. Res. 101(2), 188-190. 
Slanc, P., Doljak, B., Mlinar, A., and Itrukelj, B. (2004). "Screening of wood damaging fungi and macrofungi for inhibitors of pancreatic lipase," Phytother. Res. 18, 758-762.

Smania, A., Dell Monache, F., Smania, E. F. A., Gil, M. L., Benchetrit, L. C., and Cruz, F. S. (1995). "Antibacterial activity of a substance produced by the fungus Pycnoporus sanguineus (Fr.) Murr.," J. Ethnopharmacol. 45, 177-181.

Takara, K., Otsuka, K., Wada, K., Iwasaki, H., and Yamashita, M. (2007). “1,1-diphenyl2-picrylhydrazyl radical scavenging activity and tyrosinase inhibitory effects of constituents of sugarcane molasses," Biosci. Biotech. Bioch. 71(1), 183-191.

Taylor, W. G., Sutherland, D. H., and Richards, K. W. (2009). "Soyasaponins and related glycosides of Desmodium canadense and Desmodium illinoense," The Open Nat. Prod. J. 2, 59-67.

Teoh, Y. P., and Mat Don, M. (2011). "Kinetic model for the hydrolysis of sterilized palm press fibre," Chem. Eng. Sci. doi:10.1016/j.ces.2011.04.011

Teoh, Y. P., and Mashitah, M. D. (2010). "Cellulase production by Pycnoporus sanguineus on oil palm residues through pretreatment and optimization study," $J$. Appl. Sci. 10(12), 1036-1043.

Thomas, K. C., Hynes, S. H., and Ingledew, W. M. (1996). "Effect of nitrogen limitation on synthesis of enzymes in Saccharomyces cerevisiae during fermentation of high concentrations of carbohydrates," Biotechnol. Lett. 18, 1165-1168.

Verma, M., Brar, S. K., Tyagi, R. D., Surampalli, R. Y., and Valero, J. R. (2007). "Antagonistic fungi, Trichoderma spp.: Panoply of biological control (Review)," Biochem. Eng. J. 37, 1-20.

Webster, D., Taschereau, P., Belland, R. J., Sand, C., and Rennie, R. P. (2008).

"Antifungal activity of medicinal plant extracts; Preliminary screening studies," J. Ethnopharmacol. 115, 140-146.

Yahaya, Y. A. (2008). Biosorption of Heavy Metals by Free and Immobilized Pycnoporus sanguineus: Batch and Column Studies. McS Thesis, Universiti Sains Malaysia, Malaysia, 156 pages.

Yoshiki, K., Kim, J. H., and Okubo, K. (1994). "Saponins conjugated with 2,3-dihydro2,5-dihydroxy-6-methyl-4H-pyran-4-one from Phaseolus coccineus," Phytochemistry 36(4), 1009-1012.

Zjawiony, J. K. (2004). "Biologically active compounds from Aphyllophorales (polypore) fungi - Review,” J. Nat. Prod. 67, 300-310.

Article submitted: April 18, 2011; Peer review completed: May 17, 2011; Revised version received: May 23, 2011; Accepted: May 25, 2011; Published: May 27, 2011. 